\title{
Serum level of IL13 and expression of BCL2 in Behcet's disease
}

\author{
Hanan.M.A Darwish*, Sabila Gomaa Mousa** Noha Hamdy , \\ and Sahar Zalam. \\ Departments of Dermatology and Venereology*, General Mmedicine** and Clinical \\ Pathology. Faculty of Medicine for girls Al-Azhar University.
}

\begin{abstract}
Background BD: BCL2 family is a large family of apoptosis regulating proteins consisting of both blockers and promoters of cell death. Immunological processes and a variety of cytokines may play a role in pathophysiological process. Defective regulation of programmed cell death (apoptosis) also play a role in development of Behcet's disease

Objective: To investigate the level of BCL2 and IL13in BD and to determine their to relation monitory disease activity.

Patients and methods: This study was conducted on thirty patients (15 active and 15 inactive) and 15-health control, the activity of BD was evaluated according to international study group for BD disease, using ELISA technique for IL 13 and flow cytometry forBCL2.

Results: Elevated serum levels of IL13 in patient with active BD than inactive and both had elevated levels than control $(\mathrm{P}<0.01)$ and also the serum levels of $\mathrm{Bcl} 2$ was elevated in patient with active $\mathrm{BD}$ than inactive and control $(\mathrm{P}<0.01)$.

Concolusion: The data suggested that IL13 and BCL2 could be involved in the pathogenesis of $\mathrm{BD}$ and its serum levels can be used as marker to monitor disease activity.
\end{abstract}

\section{Introduction}

Behcet's disease (BD) is an inflammatory multisystem disorder chara-cterized by recurrent oral genital and aphthous ulcers , arthritis, uveitis and therombophlepitis that can involve several organs (Emmi et al., 1997).

Hulusi Behcet, is Turkish dermatologist, described the recurrent orogenital ulceration and uveitis in1937. The prevalence of BD is highest in Japan, south Asia ,the middle east and southern Europe .The disease is rare in northern Europe and the United state (Jorizzo,1999). Although the etiology and the pathogenesis of BD still remain uncertain, it has been suggested, that three major pathophosiologic changes, neutrophil hyperfunction, vasculitis and autoimmune response may be involved in its pathogenesis ( Sakane et al.,1997)

Recent studies have indicated that cytokine- producing cells play an important role in the immunopathogenesis of inflammation in BD (Sugi et al., 1998). In particular, a divergent cytokine production profile of $\mathrm{TH} 1 / \mathrm{TH} 2$ cell type is very important in the immune response occurring in BD (Raziuddin et al.,1998) .

Programmed cell death (apoptosis) is important in down-modulation immune response after activation and proliferation of inflammatory cells. It has been suggested that dysregulated apoptosis of lymphocytes may be linked to the development of autoimmune disease as Sjogrens syndrome (Ichikawa et al.,1995), systemic lupus erythematosus (SLE)(Aringer et al.,1991) and rheumatoid arthritis(RA) (Isomaki et al.,1996). Defective regulation of programmed cell death (apoptosis) may play a role in the development of $\mathrm{BD}$ and the protoncogene $\mathrm{Bcl}-2$ is involved in the control of apoptosis in immunocompetent cells (Hamzaoui et al., 1999).

The diagnostic criteria established by the international study group for Behcet's disease requires the presence of recurrent oral ulceration and two of the following: recurrent genital ulceration, eye lesions, 
skin lesions and/or a pathergy test. Pathergy respone is anoduleor pustule, 3-10mm, appearing 24-48 hours after puncture of the forearm Srin with sterile 20 gauge needle. (Table 1)

\section{Patients and methods}

\section{Patient group:}

Thirty patients with BD were studied (15 active and15 inactive).The active group,the sex (M/F 13/2) , aged (30-41)the mean $(40.40 \pm 587)$.Inactive group 15 patients (M/F 12/3) aged (32-44) The mean $(41.80 \pm 5.89)$ the activity was evaluated according to international study group of Behects disease. We collected the patients from out patient clinic of dermatology ,internal medicine and ophthalmology $\mathrm{Al}$ Zahraa hospital, Al-Azhar university and otherhospitals .

\section{Control group:}

15 healthy subjects (M/F 9/6) aged $(22-45)$ years, the mean $(35.93 \pm 1.31)$ years were served as control group.

All patients and control group were subjected to the following:

Full history, thorough clinical examination, complete blood picture, erythrocyte sedimentation rate (ESR), fundus examination, serum IL 13 and $\mathrm{Bcl}_{2}$.

\section{Sample collection \& storage:}

A fresh peripheral blood sample is collected by veni-puncture and divided into two tubes, one empty tube for serum sample and the other with heparin for lymphocyte separation.

\section{Measurement of IL-13:}

Serum sample was used for estimation of $\mathrm{IL}-13$ using ELISA technique (Biosource international).

\section{Determination of BCL2:}

Heparin blood sample was used for separation of lymphocyte by FicallHypique density-gradient centrifugation \& washed twice with PBS at $+4^{\mathrm{oC}}$. Then add $20 \mathrm{Ml}$ of Antigen Extraction Agent (AEA) for every $100 \mathrm{Ml}$ of cell suspension of incubate 30 minutes on ice with the occasional vortexing then transfer extracts to micro-centrifuge tubes and centrifuge for 5 minutes. The samples are now ready for analysis by Bender Med systems human BCL-2 ELISA.

\section{Results}

Thirty patients (15 active and 15 inactive). Active patient with BD (male to female ratio $13 / 2(86.87 \%$ - $13.33 \%)$ age ranged (30-41) the mean (40.4 $\square$ 5.87), inactive $\mathrm{BD}$ male to female $12 / 3 \quad(80 \%$ $20 \%)$ age ranged (32-44) the mean $(41.80$ $\square$ 5.89) and control 15 healthy subject male to female (9-6) age (22-45) the mean (35.93 $\square$ 7.31)table (2and 3).

Table (4) shows some clinical date of some patients with $\mathrm{BD}$.

Table (5)shows that Serum levels of IL13 are higher in-patient with active BD (73.4 $\square$ 14.41) than in patients with inactive BD (7.27 $\square .06)$ and control (2.73

2.05). This difference were statistically significant $(\mathrm{P}<0.01$ and $\mathrm{P}<0.01))$ respectively. Also, it was noted that serum IL13 level in inactive group was significantly higher than normal control group $(\mathrm{p},<0.01)$ (figure 2)

Serum levels of BCL2 is higher inpatients with active BD than inactive and both are higher than control (73.4 $\square 14.41)$, $(7.27 \square 3.06)$ and $(2.73 \square 2.05)$, respectively with significance difference $(\mathrm{P}<$ 0.01) for all difference.

On comparing BCL2 in active BD with control there were statistically significance $(\mathrm{P}<0.01)$. On comparing BCL2 inactive with control there was statistically significance $(\mathrm{P}<0.01)$. Table $(6)$ and figure (3).

ESR is higher in-patient with active BD than in-patient with inactive and control group. This difference was statistically significant. Table (7) and figure (1). 
(Table 1)

Criteria for the diagnosis of Behcet's syndrome

International study group for Behcet's disease

In the absence of other clinical explanation, patients must have:

1- Recurrent oral ulceration: (Aphthous or herpetiform recurring at least 3 times in 1 year period and 2 of the following:

2- Recurrent genital ulceration.

3- Eye lesion: Anterior or post-uveitis, cells in the vitreous by slit lamp examination or retinal vasculitis observed by an ophthalmologist.

4- Skin lesions: Erythema nodosum, pseudo-folliculitis, papulopustular lesions or acneiform nodules in post adolescent patients not on corticosteroids.

5- Pathergy, read at $24-48$ hours.

(Mouts, 1994)

Table (2) shows the sex in patients and control

\begin{tabular}{|c|c|c|c|c|c|c|}
\hline SEX & $\begin{array}{c}\text { Active group } \\
\text { number }\end{array}$ & $\%$ & $\begin{array}{c}\text { Inactive group } \\
\text { number }\end{array}$ & $\%$ & $\begin{array}{c}\text { Control group } \\
\text { number }\end{array}$ & $\%$ \\
\hline females & 2 & 13.33 & 3 & 20 & 9 & 60 \\
\hline males & 13 & 86.67 & 12 & 80 & 6 & 40 \\
\hline total & 15 & 100 & 15 & 100 & 15 & 100 \\
\hline
\end{tabular}

Table (3) shows the age in patient and control.

\begin{tabular}{|c|c|c|c|c|c|}
\hline Age (mean $\square$ SD) & Control group & Active group & T value & P value & \\
\hline \multirow{7}{*}{} & $35.93 \square 7.31$ & $40.40 \square 5.87$ & 1.86 & $>0.05$ & NS \\
\cline { 2 - 6 } & Control & Inactive & T value & P value & \\
\cline { 2 - 6 } & $35.93 \square 7.31$ & $41.80 \square 5.89$ & 2.42 & $>0.05$ & NS \\
\cline { 2 - 7 } & Inactive & Active & T value & P value & \\
\cline { 2 - 7 } & $41.80 \square 5.89$ & $40.40 \square 5.87$ & 0.65 & $>0.05$ & NS \\
\hline
\end{tabular}

Table (4):- clinical features of some patients with active Behcet's disease

\begin{tabular}{|l|l|l|l|l|l|}
\hline Patient & Disease & \multicolumn{3}{|l|}{ Symptoms } & \\
\hline $\mathbf{1}$ & Active & Oral & Genital & Uveitis & \\
\hline $\mathbf{2}$ & Active & Oral & Genital & Uveitis & Arthritis \\
\hline $\mathbf{3}$ & Active & Oral & Genital & Uveitis & EN \\
\hline $\mathbf{4}$ & Active & Oral & Genital & & Pulmonary \\
\hline $\mathbf{5}$ & Active & Oral & & & \\
\hline $\mathbf{6}$ & Partial & & & & \\
\hline $\mathbf{7}$ & Active & Oral & Genital & & Acneiform \\
\hline
\end{tabular}


Table (5) shows the serum level of IL-13 in patients and control group.

\begin{tabular}{|l|l|l|l|l|l|}
\hline IL-13 (mean $\square$ SD) & Control & Active & T value & P value & Significance \\
\hline & $2.73 \square 2.05$ & $73.40 \square 14.41$ & 18.80 & $<0.01$ & HS \\
\cline { 2 - 6 } & Control & Inactive & T value & P value & Significance \\
\cline { 2 - 6 } & $2.73 \square 2.05$ & $7.27 \square 3.06$ & 4.77 & $<0.05$ & S \\
\cline { 2 - 6 } & Inactive & Active & T value & P value & Significance \\
\cline { 2 - 6 } & $7.27 \square 3.06$ & $73.40 \square 14.41$ & 17.37 & $<0.01$ & HS \\
\hline
\end{tabular}

Table (6) shows the serum level of BCL2 in patients and control group

\begin{tabular}{|l|l|l|l|l|l|}
\hline BCL2 (mean $\square$ SD) & Control & Active & T value & P value & Significance \\
\hline & $6.47 \square 2.50$ & $147.73 \square 31.76$ & 17.16 & $<0.01$ & HS \\
\cline { 2 - 6 } & Control & Inactive & T value & P value & Significance \\
\cline { 2 - 6 } & $6.47 \square 2.50$ & $29.73 \square 11.16$ & 7.87 & $<0.01$ & HS \\
\cline { 2 - 6 } & Inactive & Active & T value & P value & Significance \\
\cline { 2 - 7 } & $\begin{array}{l}29.73 \\
1116\end{array}$ & $147.73 \square 31.76$ & 13.57 & $<0.01$ & HS \\
\hline
\end{tabular}

Table (7) shows the ESR in patient and control.

\begin{tabular}{|c|c|c|c|c|c|c|c|}
\hline ESR (mean $\square \mathrm{SD}$ ) & \multicolumn{2}{|c|}{ Control } & \multicolumn{2}{|l|}{ Active } & $\mathrm{T}$ value & $\mathrm{P}$ value & \\
\hline & 13.07 & $\square$ & $\begin{array}{l}82.67 \\
\end{array}$ & $\square$ & 20.19 & $<0.01$ & HS \\
\hline & Contro & & Inactiv & & $\mathrm{T}$ value & $\mathrm{P}$ value & \\
\hline & 13.07 & $\square$ & 23.67 & $\square$ & 6.66 & $<0.01$ & HS \\
\hline & Inactiv & & Active & & $\mathrm{T}$ value & $P$ value & \\
\hline & 23.67 & $\square$ & 82.67 & $\square$ & 16.23 & $<0.01$ & HS \\
\hline
\end{tabular}




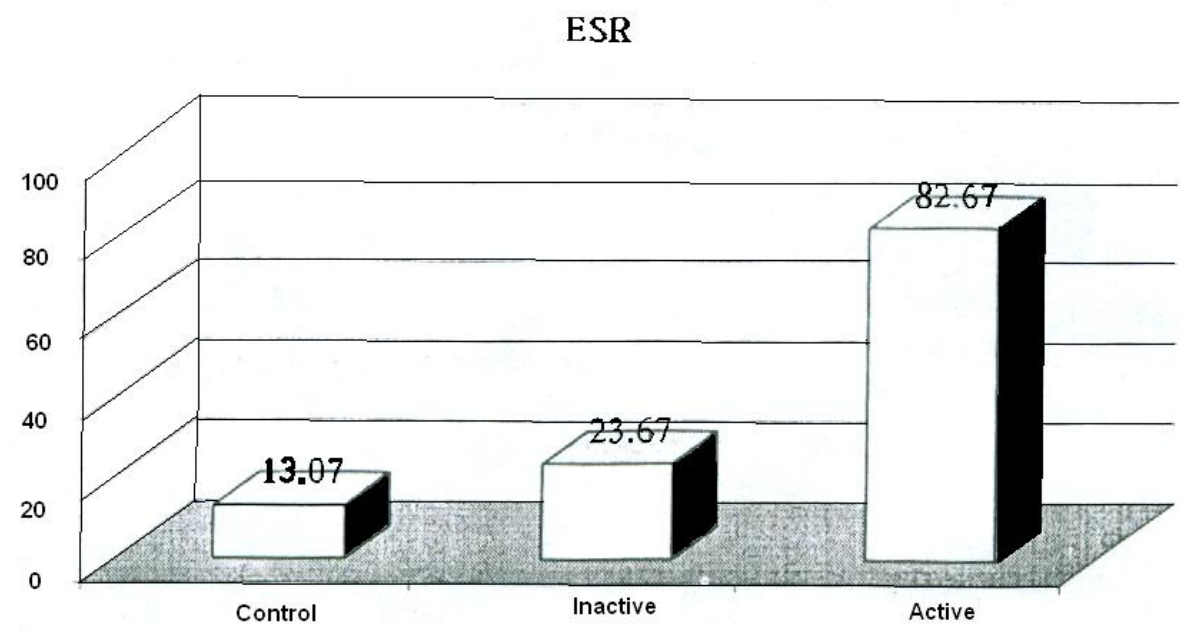

Fig ( 1 ) Comparison of ESR level in control, inactive and active groups

IL-13

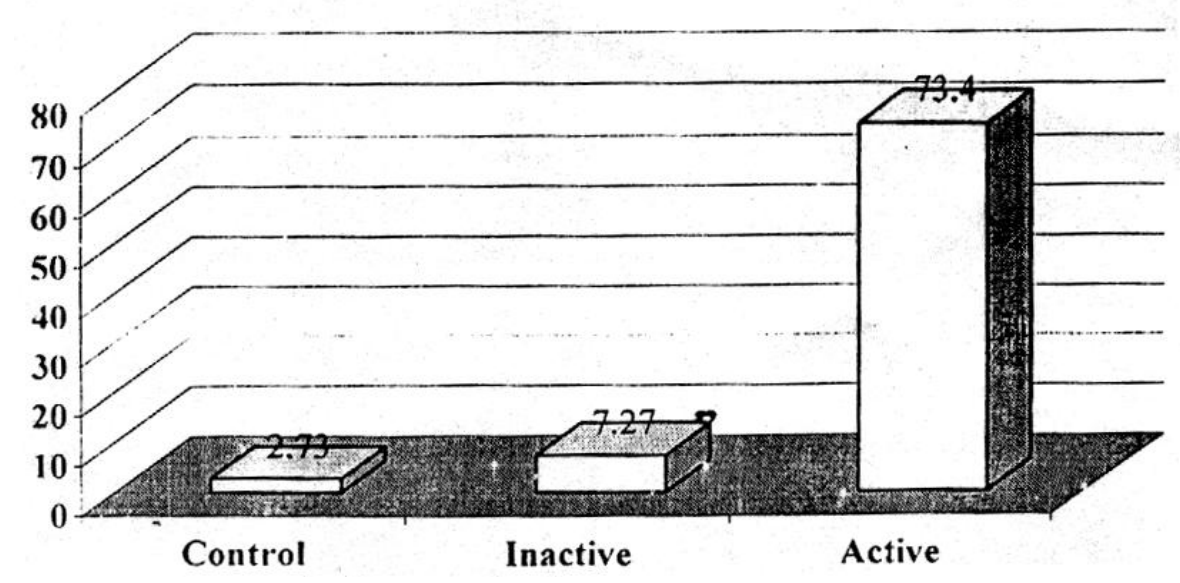

Fig ( 2 ) Comparison IL-13 in control, inactive and active groups

$\mathrm{BCl} 2$

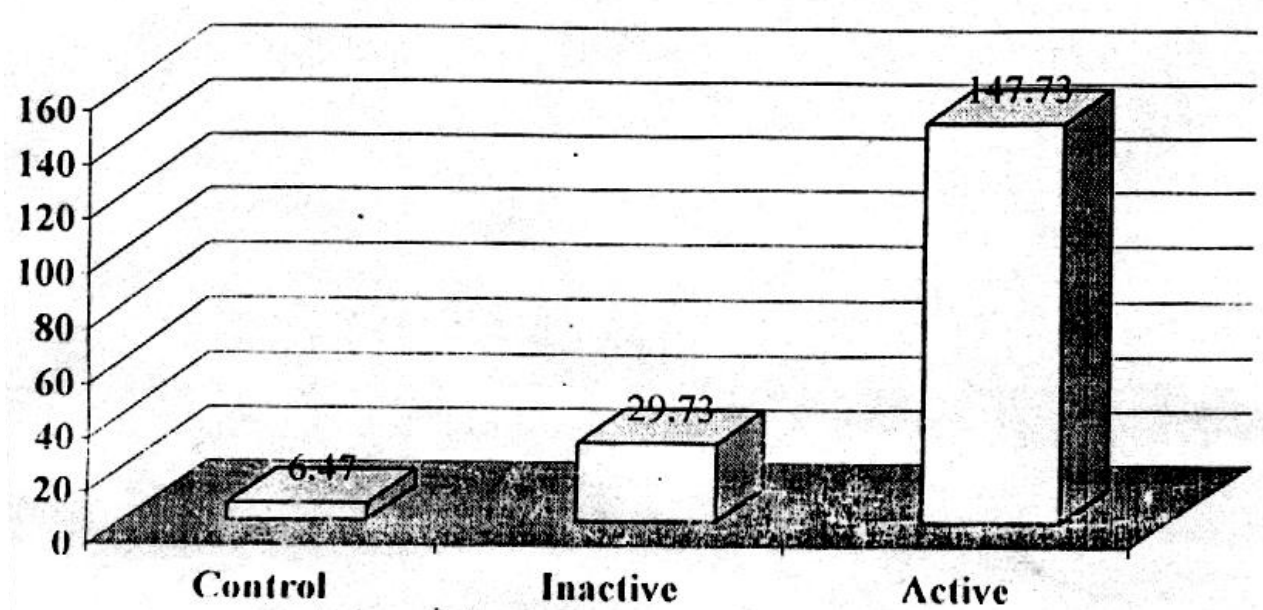

Fig ( 3 ) Comparison of $\mathrm{BCl} 2$ level in control, inactive and active groups 


\section{Discussion}

Bechet's is a polysymptomatic disease, as a result of recurrent systemic vasculitis with choronic course and unknown acetiology (Emmi et al., 1997). Several organs or systems can be involved and the symptomatology and severity depend on the system affected, The main clinical features are: oral aphthous, genital ulcers, ocular lesion,skin lesion, arthritis,central nervous system affection, vasculitis and other less frequent findings such as pulmonary manifestation (Jorizzo,1999). Increasing evidences indicate that immunological processes and a variety of cytokines may contribute to the pathophysiological process in BD (Sakane et al.,1997).

Recently it was reported that patients with BD have a dysregulation of programmed cell death (Hamzoui et al.,1998). BCL2 is a proto-oncogene that regulates apoptosis of several cell types, BCL2 plays a role in the maintenance of the immune system, since inactivation of BCL2 in mice leads to the disappearance of the lymphoid system (Nakayama and Neghishi,1993). Lymphocyte activation in active BD was increased, in particular in the inflammatory sites (Hamzaoui et al.,1999). So it is possible that the expression of apoptosis-regulating proteins, like BCL2, is dysregulated in these lymphocytes.

In our study we found that the serum level of IL13 was significantly higher in active BD than inactive and both had higher level than control group .

These results are agreement with that of Razidudin et al., ( 1998), AL-dalaam et al ,1998), andAridogam et al (2003) who reported that serum IL13 level were higher in patient with active BD than inactive and control. In contrast to these results two studies were done by Lehner, (1999) and Mantas et al., ( 1999 ) reported that there is no statistically significance difference between BD patients and controls as regard serum level of IL13.
We have found that the serum levels of BCL2 was higher in patient with active BD than inactive and both had higher levels than control. These results agree with data done by Hamzaoui et al. ( 1996) and Hamzaoui et al. (1999) and also other data done by Isömak, ( 1996) who reported that increased expression of $\mathrm{Bcl} 2$ in BDand SLE. The possible explanation for the increased BcL2 expression in the peripheral blood and inflammatory sites in BD disease was the increased in production of IL2 (Hamzaoui and Ayed,1990), because IL2 has been shown to increase BcL2 expression in active T-cells (Deng and Podak,1993).

The increased BcL2 protein expression in active $\mathrm{BD}$ is non specific for the disease and may be explained at least in part by the increased in vivo activation levels or presence of autoimmune vasculitis combined with in vivo inducation by aetiopathological agents. These may play an important role in the chronic inflammation in $\mathrm{BD}$ (Hamzaoui et al.,1998).

\section{Reference:}

1- AL- Dalaan A, Al- Shaikh A, Bahabri S, Al- mayouf $S$ and El Kholfa M (1998): Study of HLA class 2 antigens allele distribution in Behcet's disease among small population, $8^{\text {th }}$ International Congress on Behcet's Disease., 11.

2- Aridogon BC, yildirim M, Baysal V, Inaloz HS, Baz K and Kayu S (2003): Serum levels of IL-4, IL- 10, IL- 12, IL- 13 and IFN- Gamma in Behcet's disease. J. Dermatol., 30: 602- 607.

3- $\quad$ Aringer $M$, WinterSherger $\mathbf{W}$, Steiner CW, Kierner H, Presteri E, Jaeger U, Smolen JS and Graninger WB (1994): High level of $\mathrm{Bcl}_{2}$ protein in circulating Tlymphocytes but not B-lymphocytes of patients with systemic lupus erythematosus. Arthr Rheum., 37:1423-1430.

4- Deng G and podak ER (1993): Suppression of apoptosis in cytotoxic Tcell line by interleukin 2 mediated gene 
transcription and deregulated expression of the proto-oncogene $\mathrm{Bcl}_{2}$. Proc Natl Acad Sci USA., 90: 2189-2193.

5- Emmi L, Brugnolo F, Marchione T (1997): pathogenesis and therapy of Behcet's disease. Ann Ital Med Int., 12:20- 25.

6- Hamzaoui A, Hamzaoui $K$ and Chabbou A (1996): A high levels of $\mathrm{Bcl}_{2}$ protein in T- lymphocytes of patients with Behcet's disease; Clin Exp Rhumatol., 14: 106- 108.

7- Hamzaoui K and Ayed K (1990): High affinity IL- 2 receptors on peripheral blood lymphocytes are decreased during active Behcet's disease. Clin Exp Rhumatol., 8: 100- 101.

8- Hamzaoui K, Hamzaoui A, Zakaraoui L and Chabbou A (1998): Fas/ APO-1 in patients with Behcet's disease. Mediators inflamm., 7:111-114.

9- Hamzaoui K, Hamzaoui A, Zakaraoui L and Chabbou A (1999): Expression of $\mathrm{Bcl}_{2}$ in inflammatory sites from patients with active Behcet's disease in mediators of inflammation., 8: 101-106.

10- Ichikawa Y, Arimori K, Yoshida $M$ and Hoshina Y (1995): Abnormal expression of apoptosis regulated antigens, Fas and $\mathrm{Bcl}_{2}$ on circulating $\mathrm{T}$ - lymphocyte subsets in primary Sjogren syndrome. Clin Exp Rhumatol., 13: 307- 313.

11- Isomäki P, Södersteöm KO, punnonen J, Roivainen A, Luukkainen R, Merilahtipaolo $R$, Nikkari S, Lassila $O$ and Toivanen P(1996): $\mathrm{Br} \mathrm{J}$ Dermatol., 35:611- 619.

12- Jorizzo JL (1999): Behcet's disease. In Freedberg IM, Eisen AZ, Wolff K, Austen
KF, Goldsmith LA, Katz SI, Fitzpatric TB (eds): dermatology in general medicine, McGraw- Hill, New York, pp: 2161-2165.

13- Lehner T (1999): Immunopathogenesis of Behcet's disease. Ann Med Interre., 150: 483-487.

14- Mantas C, Direskeneli H, EksiogluDemiralp E and Akoglu T (1999): Serum levels of Th-2 cytokines, IL- 4 and IL- 10 in Behcet's disease. J Rhumatol., 26: 510512.

15- Mouts poulas HM (1994): Behcet's Syndrome. In; Isselbsacher KJ, Braun Wald E, Wilson JD, Martin JB and Fauci AS, eds. Harrison's principles of internal medicine, USA. Mc Graw. Hill Inc., 16691670.

16- Nakayama $K$ and Naghisi I (1993): Disappearance of the lymphoid system in Bcl-2 homogenous mutant chimeric mice. Science., 261:1584- 1588.

17- Razidudin S, Al Dalaan S, Siraj Ak and Al Sedwry S (1998): Divergent cytokine production profile in Behcet's disease. Altered Th1/ Th2 cell cytokine pattern. J Rhumatol., 25: 329-333.

18- Sakane T, Suzuki Nand Nagafuchi H (1997): Etiopathology of Behcet's disease: Immunological aspects. Yonsei Med J., 38:350-358.

19- Sugi-Ikai N, Nakazawa M, Nakkamura S, Ohano S, Minami M (1998): Increased frequencies of interleukin-2 and interferongamma- producing $\mathrm{T}$ cells in patients with active Behcet's disease. Invest Ophthalmol Vis sci., 39:996-1004. 


\section{تحديد مستوى الإنترلوكين 13و ب س ل 2 فى مرضى بهست}

\section{د/ نهى حمدى" ـ د/حنان محمد على درويش* * ـ د/ وسيلة جمعة موسى *** ـ د/

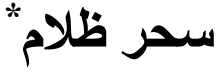 \\ قسم التحاليل الإكلينيكية* و قسم الأمر اض الجلدية و التناسلية*** و قسم الباطنة العامة***}

يعد مرض بهست من الأمر اض الإلتهابية التى تصيب عدة أجهزة من الجسم معاو

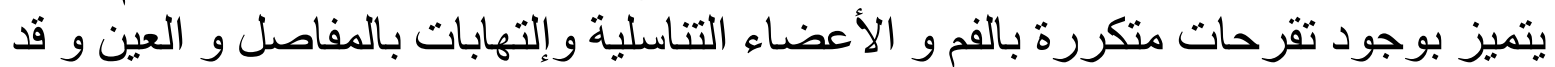

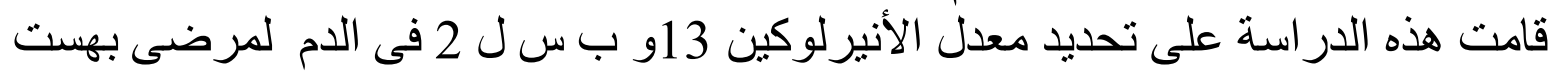

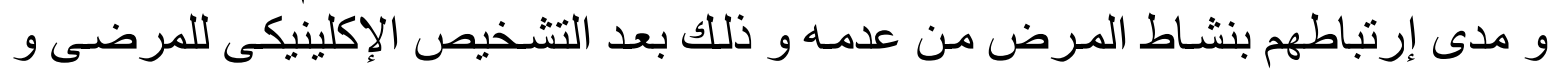

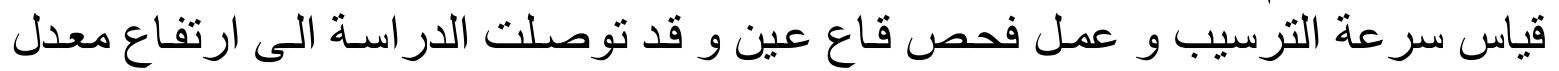

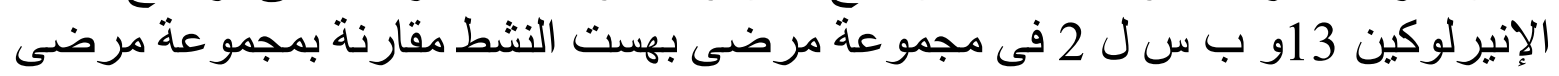
بهست الغير نشطو المجموعة الضابطة. 